\title{
Partial or total replacement of commercial concentrate with on-farm-grown mulberry forage: effects on lamb growth and feeding costs
}

\author{
A. Alpízar-Naranjo ${ }^{1}$ - J. Arece-García ${ }^{2}$ - M. Esperance ${ }^{2} \cdot$ Y. López $^{2} \cdot$ M. Molina $^{2}$. \\ E. González-García ${ }^{3}$
}

Received: 5 April 2016 / Accepted: 17 January 2017 /Published online: 23 January 2017

(C) Springer Science+Business Media Dordrecht 2017

\begin{abstract}
Replacing commercial concentrate with mulberry foliage was evaluated in a feeding trial lasting 126 days. Forty-eight weaned male Pelibuey lambs $(20.6 \pm 0.80 \mathrm{~kg}$ of BW) were randomly allocated to four groups: (1) supplementing the basal diet with mulberry at $1 \%$ (DM basis; $\mathrm{M}-1),(2)$ mulberry at $0.75 \%$ plus $0.1 \mathrm{~kg}$ concentrate fresh matter basis (M-0.75), (3) mulberry at $0.50 \%$ plus $0.2 \mathrm{~kg}$ concentrate $(\mathrm{M}-0.50)$ and (4) basal diet plus $0.3 \mathrm{~kg}$ concentrate (control; M-0). During the first 90 days, the basal diet was Pennisetum purpureum forage which was substituted by a mixture of guinea grass and sugarcane from 90 days. Average daily gain (ADG, g/day), dry matter intake (DMI) and feed conversion rate (FCR; DMI/ADG) were determined. The ADG was affected $(P<0.01)$ by the diet, with the lowest obtained in M-1 lambs (71 $\pm 6.4 \mathrm{~g} /$ day $)$, whereas no differences among the other groups were observed $(94 \pm 6.4 \mathrm{~g}$ $\mathrm{DM} / \mathrm{lamb})$. The DMI was higher $(P<0.01)$ in $\mathrm{M}-0(937 \mathrm{~g}$ $\mathrm{DM} / \mathrm{lamb}$ ) which concomitantly affected differences in FCR $(11.9,9.9,10.5$ and $9.7 \mathrm{~kg}$ DMI/kg BW gain for M-1, M-0.75, M-0.50 and M-0 lambs, respectively). Final BW at slaughtering and hot or cold carcass yields were coherent with growth rate findings. Biological yield (cold carcass weight/ empty BW) was higher $(P<0.01)$ in $\mathrm{M}-0.75$. Without compromising animal productivity, replacing imported
\end{abstract}

E. González-García

eliel.gonzalez-garcia@inra.fr

1 Escuela de Ciencias Agrarias, Facultad de Ciencias de la Tierra y el Mar, Universidad Nacional de Costa Rica, Heredia, Costa Rica

2 Estación Experimental de Pastos y Forrajes "Indio Hatuey", Central España Republicana, CP 44280 Matanzas, Cuba

3 INRA UMR868, Systèmes d'Elevage Méditerranées et Tropicaux (SELMET), 34060 Montpellier Cedex 1, France concentrate with mulberry reduced the feeding cost. Optimum results were obtained with M-75 diet. Further studies must be conducted for optimizing energy/protein ratios with different ingredients while increasing DMI and lamb growth rates in this tropical genotype.

Keywords Growth · Tropical lambs $\cdot$ Mulberry forage supplementation $\cdot$ Concentrate substitution

\section{Introduction}

Sheep (and small ruminant) production is an important practice of many rural families in developing tropical countries, where low input systems are very often. In Cuba, sheep stock is currently estimated at 2,035,000 heads (FAOSTAT 2015), but despite representing one of the main sources of protein, at present, per capita consumption of sheep meat $(0.5 \mathrm{~kg} /$ year $)$ is still very low (Herrera et al. 2010) due to difficulties in covering market demands.

The dominant production systems in the island are based on extensive grazing of natural pastures which are mainly affected by seasonal variation in forage yield and nutritive value. These uncertain feed bases impact directly key parameters linked to reproduction efficiency and health, thus leading to low flock productivity and growth rates $(50-60 \mathrm{~g} / \mathrm{lamb} /$ day; Fonseca et al. 2011; Herrera et al. 2010). The first efforts for improving such extensive systems were the establishment of intensive grazing systems with grasses of higher nutritive value and DM yield, mostly in sheep-breeding farms (Perera and Albuernez 1993). These systems, with energy and protein supplementation, may achieve excellent productive performances (e.g. above $200 \mathrm{~g} /$ lamb/day) but are highly dependent from external inputs.

Due to the scarcity of concentrates and the prices of raw materials in the market, it is imperative to find local alternatives enhancing flock productivity, farm profitability and 
family economy while improving market offer. In the past, some efforts have been made, for example (i) supplementing with sugarcane (Saccharum officinarum), crop residues and agroindustrial by-products (Albuerne et al. 1996; Borroto et al. 1991; Pedraza et al. 1995); (ii) integrating sheep with the production of other fruit trees (e.g. citrus, coconut, mango, avocado) (Borroto et al. 2007; Mazorra et al. 2003, 2004); or (iii) developing the agroforestry and agrosylvopastoral systems by, e.g. establishing high-density protein banks in the grazing areas.

In this context, several works have reported the potential of the mulberry (Morus alba) forage for sustainable ruminant production in Cuba (Martín et al. 2007; Soca et al. 2010; González-García and Martín Martín 2016; González et al. 2001, 2008) and other places (Kandylis et al. 2009; SalinasChavira et al. 2011). However, little information is available in sheep fed with mulberry, even if nowadays agricultural surfaces continue to increase in the island for this purpose. Thus, the objective of this work was to evaluate the effects of substituting the commercial concentrate with different levels of the on-farm-produced mulberry forage on growth, carcass yield and overall productive performance of tropical weaned Pelibuey lambs during a 4-month fattening growth period. Effects on feeding system cost were also evaluated.

\section{Materials and methods}

\section{Experimental design. Location site, animals, feedstuffs and procedure}

This study was developed at the small ruminant facilities of the Experimental Station "Indio Hatuey", Perico, Matanzas, Cuba (EEIH; latitude $22^{\circ} 49^{\prime} 10.20^{\prime \prime} \mathrm{N}$, longitude $81^{\circ} 00^{\prime}$ $53.77^{\prime \prime} \mathrm{W}$; elevation $25 \mathrm{~m}$ above sea level). The animal experimentation was carried out under confinement such that stables of $3 \times 5 \mathrm{~m}$ with cemented floor covered for rice straw, an individual living space of $1.5 \mathrm{~m}^{2}$ by lamb and linear feeders (with frontal space of $0.25 \mathrm{~m} / \mathrm{lamb}$ ) were used.

Forty-eight weaned tropical Pelibuey lambs (average 6 months old and $20.6 \pm 0.8 \mathrm{~kg}$ of initial body weight, BW) were randomly chosen from the EEIH experimental flock for an experiment lasting 126 days. Under this kind of systems in Cuban conditions, weaning age is normally planned around 4 months old. The fact that lambs could be considered a bit old regarding the average of works dealing with fattening lambs is related to the relatively low average daily gain (ADG) rates obtained from lambing to weaning. To start the experiment, we waited for having reached at least an average of $20 \mathrm{~kg}$ of BW for the totality of lambs implied in the work. Thus, the experiment started approximately 2 months after weaning. Further details related to the experimental design are illustrated in Fig. 1.

Table 1 shows the chemical composition of the feeds used in the diets supplied to the four experimental groups. Initially, the basal forage was king grass (Pennisetum purpureum $\mathrm{cv}$. king grass). Total biomass availability of the king grass forage bank was limiting at the experimental farm; thus, it was offered to the totality of lambs only during the first 90 days of the experiment. At that point, and until the end of the measurement period, a proportional forage mixture of Guinea grass (Megathyrsus maximus cv. Likoni) and sugarcane (Saccharum officinarum) replaced the king grass as the roughage basal diet to complete the energy requirements of the animals (Fig. 1). A prepared pre-mixture of sugarcane molasses with urea $(3 \%)$ was individually and daily distributed (100 g/lamb/day) as a readily fermentable carbohydrate source. Mineral salts and clean and fresh water were available ad libitum.

The mulberry (M. alba cv. Linn) forage used was harvested daily at cutting intervals of 90 days in a forage bank, located in
Fig. 1 Illustration of the experimental time frame, treatments $(n=4)$ and other measurement details. The experiment (12 lambs/treatment) started early September, 2 months after weaning (July), and lasted 126 days (14 days of adaptation and 112 days for data collection). The vertical dashed line (early December) indicates the change of the forage basal diet after 90 days of the start of the experiment (i.e. from chopped Pennisetum purpureum to a mixture of guinea grass and sugarcane)

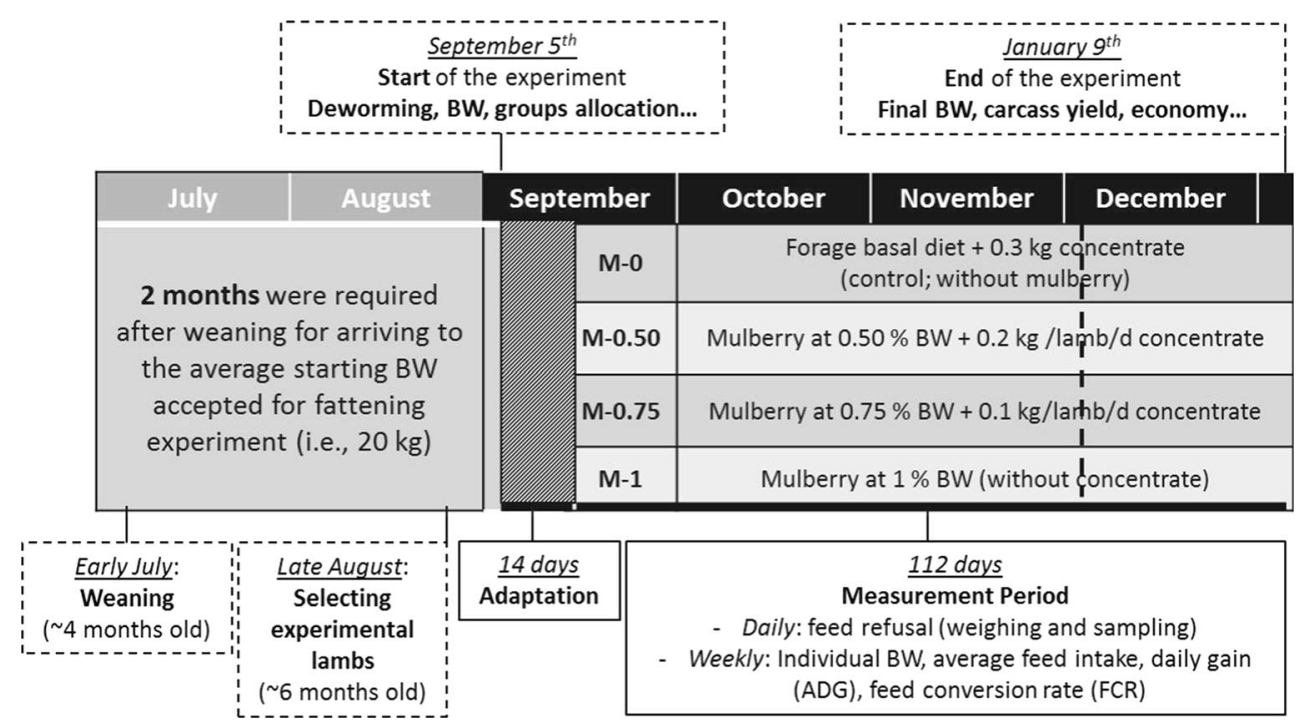


Table 1 Average chemical composition (\%) and in vitro dry matter digestibility (IVDDM, \%) of feedstuffs and ingredients used in the diets of tropical Pelibuey lambs

\begin{tabular}{|c|c|c|c|c|c|c|c|c|c|c|c|}
\hline Feedstuffs & $\mathrm{DM}$ & $\mathrm{CP}$ & NDF & $\mathrm{ADF}$ & IVDDM & Ash & $\mathrm{Ca}$ & $\mathrm{P}$ & $\mathrm{ME}^{\mathrm{a}}$ & PDIN $^{\mathrm{b}}$ & $\mathrm{PDIE}^{\mathrm{c}}$ \\
\hline King grass & 19.0 & 6.9 & 63.0 & 32.7 & 50.7 & 11.0 & 0.57 & 0.21 & 2.11 & 35 & 58 \\
\hline Guinea grass & 21.2 & 10.6 & 65.8 & 36.0 & 52.1 & 9.7 & 0.65 & 0.13 & 2.00 & 35 & 56 \\
\hline Whole sugarcane forage & 20.3 & 1.8 & 41.6 & 24.2 & 62.0 & 3.2 & 0.16 & 0.12 & 2.20 & 13 & 51 \\
\hline Mulberry forage & 25.2 & 20.9 & 26.3 & 16.9 & 86.9 & 9.0 & 1.55 & 0.26 & 2.40 & 137 & 131 \\
\hline Concentrate & 86.2 & 22.3 & 10.4 & 4.1 & 95.7 & 7.0 & 1.60 & 0.49 & 2.20 & 142 & 140 \\
\hline Molasses 3\% urea & 77.0 & 10.0 & 0.8 & 0.5 & 84.0 & 14.5 & 1.31 & 0.91 & 2.60 & 54 & 62 \\
\hline Mineral salts & 85.7 & - & - & - & - & - & 14.29 & 6.23 & - & - & - \\
\hline
\end{tabular}

${ }^{\mathrm{a}} \mathrm{ME}=$ metabolizable energy (Mcal/kg DM); estimated from Cáceres et al. (2002)

${ }^{\mathrm{b}} \mathrm{PDIN}(\mathrm{g} / \mathrm{kg} \mathrm{DM})=$ PDIA (dietary protein undegraded in the rumen which is digestible in the intestine) + PDIMN (microbial protein that could be synthesized from the degraded dietary $\mathrm{N}$ when energy is not limiting)

${ }^{\mathrm{c}} \mathrm{PDIE}(\mathrm{g} / \mathrm{kg} \mathrm{DM})=$ PDIA + PDIME (microbial protein that could be synthesized from the energy available in the rumen when degraded $\mathrm{N}$ is not limiting)

the surrounding of the experimental site. The soil for establishing these forage banks (king grass and mulberry) was prepared by combining conventional and non-conventional tillage methods during the dry season. The plantation was made, manually, at the start of the rainy season in May. Details about planting, establishment and other agronomic practices performed in these forage banks are reported by GonzálezGarcía and Martín Martín (2016).

A commercial concentrate was the main supplement source in the control diet group and was also distributed to the other groups at different rates depending on the experimental diet.

A completely randomized design was used, involving four treatments ( $n=12$ lambs per group). The experimental treatments corresponded to the diets offered during the entire fattening period, ensuring almost iso-energetic and iso-nitrogen rations (Table 2). The experimental treatments consisted of supplementing (or not) with mulberry forage on DM basis of BW as follows:

M-1: supplementing mulberry forage at $1 \%$ (dry matter (DM) basis) lambs' BW

$\mathrm{M}-0.75$ : supplementing mulberry forage at $0.75 \%$ plus $0.1 \mathrm{~kg} / \mathrm{lamb} /$ day of concentrate

$\mathrm{M}-0.50$ : supplementing mulberry forage at $0.50 \%$ plus $0.2 \mathrm{~kg} / \mathrm{lamb} /$ day of concentrate

M-0: supplementing basal diet with $0.3 \mathrm{~kg}$ of concentrate (control; without offering mulberry forage)

Before the start of the experiment, all lambs were treated against gastrointestinal parasitism with Levamisol ${ }^{\circledR}(7.5 \mathrm{mg} / \mathrm{kg} \mathrm{BW}$, LABIOFAM, Cuba). Thereafter, animals were assigned to a 14day adaptation period to familiarize with experimental conditions.

Lambs were fed twice a day (900 and 1500 hours), in two proportionally equal meals. Either the basal grasses or the edible forage of mulberry (leaves and tender stems) was mechanically chopped at an average particle size of $1.5-2.0 \mathrm{~cm}$ after harvesting in the forage bank and before distribution.

The commercial concentrate was distributed in the morning meal, combined with the $100 \mathrm{~g} / \mathrm{lamb}$ of molasses-urea (3\%) mixture. The individual feeding balance was frequently calculated (and diets adjusted) based on eventual changes in the chemical composition of the diet ingredients and the progression of lambs' nutrient requirements (Fonseca 2003).

During the whole fattening period, the individual BW was registered and monitored weekly. ADG (g/lamb/day) was calculated every week and an average value was finally considered for each treatment.

\section{Calculations of dry matter intake, feed conversion and carcass yield}

\section{Intake assessment and feed efficiency}

Dry matter intake (DMI) was calculated daily as the difference between the total amount of feed offered and the quantity of refusals weighed every morning before the first meal distribution. Total DM offered per treatment was the resultant of the quantity distributed per ingredient multiplied by the inherent DM percentage. Lambs were fed by group, i.e. one collective pen per treatment respecting a comfortable living space (i.e. $>1.5 \mathrm{~m}^{2} / \mathrm{lamb}$ ), thus avoiding competition for feed. Feeding behaviour (assessed by a routine of basic observation; data not shown) remained under normal parameters for the specie and breed throughout the experiment. A daily sample of feed refusals $(\sim 10 \%$ of total refusal per group) was collected, weighed and sent to the laboratory for DM determination. Similarly, a small sample of each ingredient distributed every day was collected for DM determination at $60{ }^{\circ} \mathrm{C}$ during $48 \mathrm{~h}$ in a forced air drying oven. At the end of each experimental week, the total amount of oven-dried samples was mixed by 
Table 2 Theoretical diet composition, energy and protein supply, according to the level of inclusion per ingredient for each experimental treatment

\begin{tabular}{|c|c|c|c|c|c|c|c|c|c|}
\hline \multirow[t]{2}{*}{$\operatorname{Diet}^{\mathrm{a}}$} & \multirow[t]{2}{*}{ Ingredient } & \multicolumn{2}{|c|}{$\begin{array}{l}\text { Daily offered, kg DM/lamb/ } \\
\text { day }\end{array}$} & \multicolumn{2}{|c|}{$\begin{array}{l}\text { Inclusion in diet, } \% \text { of diet } \\
\text { DM }\end{array}$} & \multicolumn{2}{|c|}{$\begin{array}{l}\text { Energy supply (ME), } \\
\text { Mcal/kg DM }\end{array}$} & \multicolumn{2}{|c|}{ CP supply, g/kg DM } \\
\hline & & $\begin{array}{l}\text { From } 0 \text { till } \\
90 \text { days }\end{array}$ & $\begin{array}{l}\text { From } 90 \text { till } \\
126 \text { days }\end{array}$ & $\begin{array}{l}\text { From } 0 \text { till } \\
90 \text { days }\end{array}$ & $\begin{array}{l}\text { From } 90 \text { till } \\
126 \text { days }\end{array}$ & $\begin{array}{l}\text { From } 0 \text { till } \\
90 \text { days }\end{array}$ & $\begin{array}{l}\text { From } 90 \text { till } \\
126 \text { days }\end{array}$ & $\begin{array}{l}\text { From } 0 \text { till } \\
90 \text { days }\end{array}$ & $\begin{array}{l}\text { From } 90 \text { till } \\
126 \text { days }\end{array}$ \\
\hline \multirow[t]{6}{*}{ M-1 } & King grass & 0.5 & 0 & 61.1 & 0 & 0.98 & 0 & 26 & 0 \\
\hline & Guinea-sugarcane & 0 & 0.5 & 0 & 61.1 & 0 & 0.93 & 0 & 49 \\
\hline & Mulberry & 0.21 & 0.21 & 27.7 & 27.7 & 0.50 & 0.50 & 44 & 44 \\
\hline & Molasses urea 3\% & 0.09 & 0.09 & 11.2 & 11.2 & 0.23 & 0.23 & 3.15 & 3.15 \\
\hline & Concentrate & 0 & 0 & 0 & 0 & 0 & 0 & 0 & 0 \\
\hline & Total & 0.76 & 0.76 & 100 & 100 & 1.71 & 1.66 & 72.9 & 96.1 \\
\hline \multirow[t]{6}{*}{ M-0.75 } & King grass & 0.4 & 0 & 52.7 & 0 & 0.85 & 0 & 22 & 0 \\
\hline & Guinea-sugarcane & 0 & 0.4 & 0 & 52.7 & 0 & 0.80 & 0 & 42 \\
\hline & Mulberry & 0.21 & 0.21 & 27.0 & 27.0 & 0.49 & 0.49 & 43 & 43 \\
\hline & Molasses urea 3\% & 0.09 & 0.09 & 11.2 & 11.2 & 0.23 & 0.23 & 3 & 3 \\
\hline & Concentrate & 0.07 & 0.07 & 9.2 & 9.2 & 0.15 & 0.15 & 16 & 16 \\
\hline & Total & 0.76 & 0.76 & 100 & 100 & 1.72 & 1.68 & 84.0 & 104.1 \\
\hline \multirow[t]{6}{*}{ M-0.50 } & King grass & 0.4 & 0 & 47.6 & 0 & 0.74 & 0 & 20 & 0 \\
\hline & Guinea-sugarcane & 0 & 0.3 & 0 & 42.1 & 0 & 0.61 & 0 & 32 \\
\hline & Mulberry & 0.16 & 0.16 & 21.8 & 22.2 & 0.38 & 0.38 & 33 & 33 \\
\hline & Molasses urea 3\% & 0.09 & 0.09 & 11.6 & 11.8 & 0.23 & 0.23 & 3 & 3 \\
\hline & Concentrate & 0.14 & 0.17 & 19.0 & 23.9 & 0.31 & 0.38 & 31 & 38 \\
\hline & Total & 0.71 & 0.72 & 100 & 100 & 1.66 & 1.60 & 87.4 & 107.2 \\
\hline \multirow[t]{6}{*}{ M-0 } & King grass & 0.5 & 0 & 60.4 & 0 & 0.95 & 0 & 25 & 0 \\
\hline & Guinea-sugarcane & 0 & 0.4 & 0 & 53.8 & 0 & 0.80 & 0 & 42 \\
\hline & Mulberry & 0 & 0 & 0 & 0 & 0 & 0 & 0 & 0 \\
\hline & Molasses urea 3\% & 0.09 & 0.09 & 11.4 & 11.4 & 0.23 & 0.23 & 3 & 3 \\
\hline & Concentrate & 0.21 & 0.26 & 28.2 & 34.8 & 0.46 & 0.57 & 47 & 58 \\
\hline & Total & 0.75 & 0.74 & 100 & 100 & 1.64 & 1.60 & 75.2 & 103.2 \\
\hline
\end{tabular}

${ }^{\text {a }}$ Diets or experimental treatments consisted of the level of supplementing (or not) with mulberry forage on DM basis of BW, i.e. M-1: mulberry at $1 \%$ (DM basis) of lambs' BW; M-0.75: mulberry at $0.75 \%$ plus $0.1 \mathrm{~kg} / \mathrm{lamb} /$ day of concentrate; $\mathrm{M}-0.50$ : mulberry at $0.50 \%$ plus $0.2 \mathrm{~kg}$ of concentrate; and M-0: supplementing basal diet with $0.3 \mathrm{~kg}$ of concentrate (control; without mulberry). The forage basal diet consisted of a mixture of Pennisetum purpureum (first 90 days) or Megathyrsus maximus cv. Likoni and sugarcane-Saccharum officinarum - beginning of the 90 days. A prepared premixture of sugarcane molasses with urea (3\%) was individually and daily distributed (100 g/lamb/day) as a readily fermentable carbohydrate source to all lambs. Mineral salts and clean and fresh water were constantly available ad libitum

type (individually classified per treatment, ingredient and refusal) and a small representative sample was sent to the laboratory for further chemical analyses of nutrient content (crude protein $(\mathrm{CP})$, neutral detergent fibre (NDF), acid detergent fibre (ADF), Ca, P). The metabolizable energy (ME) and protein digestible in the intestine (PDI) contents of each ingredient were estimated according to local feed composition tables (Cáceres et al. 2002). Results are presented as individual daily DMI which was estimated by dividing the total daily DMI determined per group by the number of lambs composing each experimental treatment (i.e. 12 lambs).

Once individual DMI was calculated, average daily intake was also expressed per diet ingredient and nutrient (energy and protein; Table 3), according to their respective quantities offered, refused and the determined chemical compositions.
Feed efficiency (or feed conversion rate; FCR) was calculated, weekly, as the amount of estimated total DMI required to achieve a value of ADG. It was calculated as follows: FCR $=$ DMI (g DM/lamb/day)/ADG (g/lamb/day).

\section{Carcass yield}

At the end of the experimental period, the hot and cold carcass yields were determined after slaughtering six animals per treatment. The sheep were fasted during $24 \mathrm{~h}$ and slaughtered according to standard international procedures (Suassuna et al. 2014; Kadim et al. 2004). Hot carcasses were weighed immediately after slaughter and the warm carcasses were refrigerated at $4{ }^{\circ} \mathrm{C}$ for $24 \mathrm{~h}$ post-mortem, while in the following day, the cold carcasses were weighed $(\mathrm{CCW})$. The gastrointestinal 
Table 3 Ingredients, energy (Mcal/lamb/day), protein and total feed intake (g DM/lamb/day) and average daily gain (ADG, g/lamb/day) of tropical Pelibuey lambs receiving diets with different levels of mulberry foliage after weaning. Values are least squares means

\begin{tabular}{llllll}
\hline Item & \multicolumn{2}{l}{ Treatment $(\text { diet })^{\mathrm{a}}$} & & Effect, $P$ value \\
\cline { 2 - 4 } & M-1 & M-0.75 & M-0.50 & M-0 & SEM
\end{tabular}

\begin{tabular}{lllllll}
\hline Ingredient intake & & & & & & \\
$\quad$ Basal roughage & 460 & 510 & 538 & 557 & 9.8 & $<0.0001$ \\
$\quad$ Mulberry & 294 & 226 & 153 & 0 & 4.7 & $<0.0001$ \\
$\quad$ Concentrate & 0 & 90 & 181 & 290 & 1.4 & $<0.0001$ \\
Total feed intake & 844 & 916 & 962 & 937 & 13.4 & $<0.0001$ \\
CP intake & 90 & 99 & 105 & 99 & 1.3 & 0.0332 \\
Energy intake & 1.91 & 2.05 & 2.13 & 2.05 & 0.03 & 0.0410 \\
BW change & & & & & & \\
$\quad$ Initial BW, kg & 20.7 & 20.5 & 20.8 & 20.7 & 0.80 & 0.9968 \\
$\quad$ Final BW, kg & 29.6 & 32.2 & 32.3 & 32.9 & 1.12 & 0.1754 \\
ADG & 71 & 93 & 91 & 97 & 6.4 & 0.0124 \\
FCR $^{\mathrm{b}}$ & 11.9 & 9.9 & 10.5 & 9.7 & 0.01 & 0.0032 \\
\hline
\end{tabular}

${ }^{a}$ Diets or experimental treatments consisted of the level of supplementing (or not) with mulberry forage on DM basis of BW, i.e. M-1: mulberry at $1 \%$ (DM basis) of lambs' BW; M- 0.75 : mulberry at $0.75 \%$ plus $0.1 \mathrm{~kg} / \mathrm{lamb} /$ day of concentrate; $\mathrm{M}-0.50$ : mulberry at $0.50 \%$ plus $0.2 \mathrm{~kg}$ of concentrate; and M-0: supplementing basal diet with $0.3 \mathrm{~kg}$ of concentrate (control; without mulberry). The forage basal diet consisted of a mixture of Pennisetum purpureum (first 90 days) or Megathyrsus maximus cv. Likoni and sugarcane - Saccharum officinarum - beginning of the 90 days. A prepared premixture of sugarcane molasses with urea $(3 \%)$ was individually and daily distributed (100 g/lamb/day; assumed to be $100 \%$ consumed) as a readily fermentable carbohydrate source to all lambs. Mineral salts and clean and fresh water were constantly available ad libitum

${ }^{\mathrm{b}}$ Feed conversion rate $=$ gram of DM intake required to produce $1 \mathrm{~g}$ of average daily gain (ADG)

tract (GIT), bladder (B) and gallbladder (GB) were emptied and washed to obtain the empty body weight (EBW), which was estimated by subtracting the weights referring to the content of the GIT, B and GB from the weight at slaughter, in order to determine the biological or true yield $[\mathrm{BY}=(\mathrm{CCW})$ EBW) $\times 100$ ]. The perirenal and omental-mesenteric fat were also measured.

\section{Economic feasibility. Cost and profitability assessments}

A simple economic analysis was performed in order to compare the feasibility of assuming the here evaluated diets and the concomitant practical implications. For fattening these tropical lambs, diets represented strategies enhancing a more or less important utilization of local and on-farm-produced alternative feed resources. For this, the cost per kilogram of each ingredient offered to the animals was considered. In the case of the commercially acquired feed supplements (i.e. concentrate, sugarcane molasses at 3\% urea and mineral salts), their costs per kilogram were equivalent to the current price in the local market. By the contrary, in the case of the roughage basal diets (i.e., chopped king grass, guinea grass and sugarcane) and the local farm-grown mulberry forage used as alternative supplement, their costs per kilogram were calculated based on the cost of labour and inputs used in several activities comprised during the whole process, i.e. from planting to the distribution to lambs. Activities like preparing land, seedling and planting, maintenance of plantations during the establishment and exploitation periods (e.g. manual weeds removal, organic fertilization), daily harvesting, transporting, chopping and distributing to lambs were considered the inputs and labour time required. To simplify, the last was finally grouped in just one average, overall cost value per kilogram of forage distributed. As no chemical inputs (i.e. herbicides, pesticides and inorganic fertilizers) were used, no inherent costs for these concepts were attributed. For comparison reasons, a total average daily cost per diet was calculated considering the amount of each ingredient included and their inherent individual costs. Values (costs and prices) are expressed in Cuban pesos (CUP) and then converted to USD according to current conversion rates $(1 \mathrm{USD}=24 \mathrm{CUP})$. Cost per diet was related to the observed $\mathrm{ADG}$ and feed conversion results. The conclusions of the study resulted from a combined economical and practical feasibility interpretation, also considering key principles for the sustainability of farming systems in tropics that our research teams promote.

\section{Chemical analyses}

Feed samples were ground to pass through a 1-mm stainless steel sieve. Samples were analysed for DM (AOAC 1990; ID 950.01) and organic matter (OM) (AOAC 1990; ID 942.05). The CP content was calculated after $\mathrm{N}$ determination by the Kjeldahl method (AOAC 1990; ID 976.05). The methods of Van Soest et al. (1991) were used to determine NDF (ID 989.03) and ADF (ID 973.18), without using $\alpha$-amylase.

\section{Statistical analyses}

The effects of the experimental diet or treatment on total feed and nutrient intake as well as BW (and ADG) progression were analysed by using the PROC MIXED procedure of the SAS statistical software (SAS v. 9.3, 2003) with repeated measures. The statistical model included the experimental diet as the main fixed effect, while the date of measurement was considered for the repeated statement. The animal was included in the model as a random effect. The suitability of the covariance structures of repeated measures (compound symmetry, CS; unstructured, UN; and first-order autoregressive plus random effect, $A R(1)+R E$ ) was objectively compared using goodness of fit criteria printed by MIXED procedure, including the REML log likelihood, Akaike information criterion and Schwarz Bayesian criterion. The compound symmetric covariance structure yielded the lowest Akaike 
information criterion value for each variable and was chosen. Non-orthogonal contrasts between diets were performed for comparing treatments. In the analyses of carcass yields, a similar model was used taking into account the BW at slaughter as a covariate. Significance was declared at probability levels of 95\% $(P \leq 0.05)$. Comparisons between means were tested by the LS means procedure of SAS.

\section{Results}

Table 3 shows the average total feed intake, ingredient, CP and energy intakes for each group of lambs receiving the different experimental diets. The BW changes and growth (ADG) as well as the FCR are also presented.

The diet supplemented by just mulberry foliage (M-1) and that supplemented by just commercial concentrate (M-0) showed, respectively, the lower and higher values of total feed intake throughout the whole experimental period (Table 3). Basal roughage intake increased proportionally to the increase of concentrate in the diet. Total feed intake increased until the inclusion of $200 \mathrm{~g}$ of concentrate (diet M-0.50). Comparing groups with different levels of concentrate, differences in total DMI were only observed between diets M-0.75 and M-0.50 (916 vs. 962 g DMI, respectively). The highest and lowest CP and energy intakes were observed in the M-0.50 and M-1 diets, respectively, whereas no differences were found between the control and M-0.75 diets (Table 3).

The average final BW of lambs was above $29.5 \mathrm{~kg}$ (Table 3) and ranged between $29.6 \pm 1.12$ and $32.9 \pm 1.12 \mathrm{~kg}$ per lamb. Only the lambs from the M-1 treatment, receiving mulberry forage at the highest level, showed significant differences $(P<0.05)$ when compared to the other experimental treatments (M-0, M-0.50 and M-0.75) presenting similar final BW. Growth rate or average ADG for the period (Table 3 ) was lower $(P<0.01)$ in these lambs, although no differences were found for the rest of the treatments as illustrated by BW progression (Fig. 2). Changing the basal diet (after the first 90 days) was followed by a positive effect upon growth particularly for the group receiving $100 \%$ mulberry (Fig. 2), which is probably the consequence of a higher energy density of the basal roughage source including sugarcane (Tables 1 and 2).

The lower BW progression in the M-1 group was related with the lower total DMI and their concomitant lower ADG (Table 3). This was much related to the worst FCR obtained in this treatment which was depressed until $23 \%$ when compared to the control diet (M-0). The FCR was 11.9, 9.9, 10.5 and $9.7 \mathrm{~kg} \mathrm{DMI} / \mathrm{kg} \mathrm{BW}$ gain for M-1, M-0.75, M-0.50 and M-0, respectively. The M-0.75 diet showed similar FCR to the control ( $<10 \mathrm{~g}$ DMI required to produce $1 \mathrm{~g}$ of $\mathrm{ADG})$.

Carcass traits and yields are reported in Table 4. In agreement with the final BW differences, either hot or cold carcass

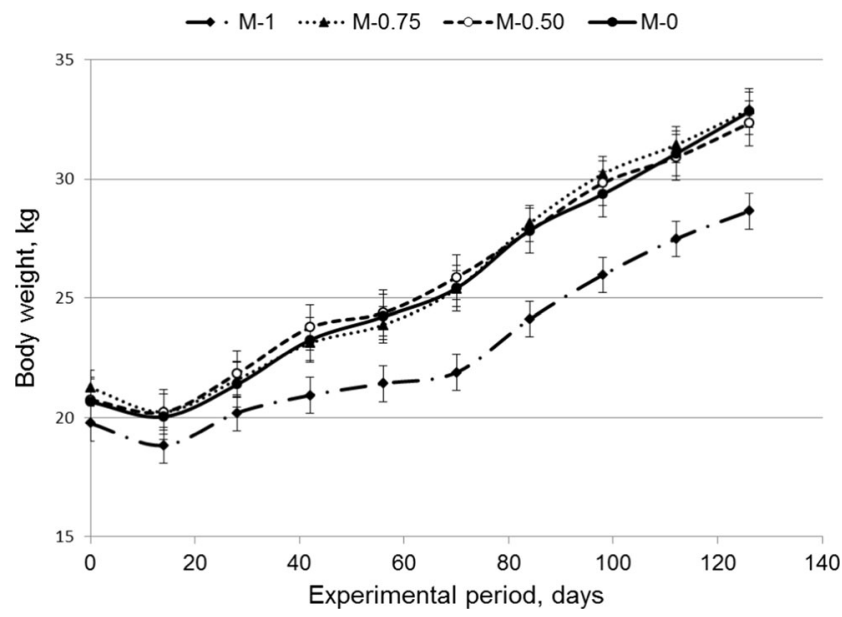

Fig. 2 Body weight progression, from weaning to slaughtering, of male Pelibuey lambs fattened in confinement and receiving (or not) different levels of mulberry forage in the diet

yields were better in the M-0.75, M-0.50 and M-0 treatments when compared to M-1 lambs. After calculating the EBW, the best biological yields (CCW/EBW) were obtained with the M-0.75 diet (63\%). Surprisingly, the lowest biological yield was found for the diet consuming the highest amount of concentrate (control, M-0), as a direct consequence of the lower cold carcass weight obtained in this group.

The economic feasibility of fattening lambs' diets with different levels of commercial concentrate replaced by mulberry forage appears in Table 5. Basal roughage and concentrate cost were progressively reduced as the level of mulberry forage increased in the diet. Consistently, total feeding cost was lower when increasing mulberry, ranging from $0.6 \mathrm{USD} / \mathrm{kg}$ of whole fresh diet in the control diet (zero mulberry) to 0.3 $\mathrm{USD} / \mathrm{kg}$ in the M-1 diet. In the same way, the cost of diet in function of the obtained average ADG was significantly reduced from the mulberry inclusion used in the M- 0.75 diet and was not different between this and the M-1 diet. The profitability, by the contrary, was in the other sense and was reduced when including the mulberry forage at $100 \%$ in the diet. However, the M-0.75 diet showed a profitability level higher than the M-0.50 diet and not far than the value obtained for the control diet (M-0).

\section{Discussion}

The high quality and nutritive value of the mulberry forage have been recognized, and such attributes are sometimes comparable to conventional sources used in livestock feeding systems like soybean or alfalfa (Doran et al. 2007; Nguyen et al. 2005). Nevertheless, there are few literature data on the use of mulberry forage in tropical growing lambs.

The high nutritive value of the edible mulberry forage and the potential of this excellent alternative protein forage source 
Table 4 Carcass traits of tropical Pelibuey lambs $(n=5$ per treatment) receiving diets with different levels of mulberry foliage. Values are least squares means

\begin{tabular}{lllllll}
\hline Item & \multicolumn{2}{l}{ Treatment (diet) ${ }^{\mathrm{a}}$} & \multicolumn{2}{c}{ Effect, $P$ value } \\
\cline { 2 - 5 } & $\mathrm{M}-1$ & $\mathrm{M}-0.75$ & $\mathrm{M}-0.50$ & $\mathrm{M}-0$ & $\mathrm{SEM}$ & \\
\hline BW at slaughtering, kg & 29.6 & 32.2 & 32.3 & 32.9 & 0.98 & 0.0792 \\
Gastrointestinal tract weight, kg & 8.5 & 9.4 & 7.7 & 8.0 & 0.43 & 0.0603 \\
Gut's weight, kg & 0.8 & 1.0 & 1.0 & 1.0 & 0.05 & 0.0972 \\
Perirenal and mesenteric fat, kg & 1.0 & 1.2 & 1.0 & 1.2 & 0.19 & 0.8071 \\
Empty body weight (EBW), kg & 19.3 & 20.6 & 22.6 & 22.7 & 0.86 & 0.0805 \\
Hot carcass weight, kg & 11.5 & 13.3 & 13.5 & 13.8 & 0.50 & 0.0242 \\
Cold carcass weight (CCW), kg & 11.3 & 13.0 & 13.2 & 12.9 & 0.48 & 0.0378 \\
Hot carcass yield, \% & 40.2 & 41.0 & 43.2 & 43.4 & 0.70 & 0.0107 \\
Cold carcass yield, \% & 39.3 & 40.2 & 42.2 & 40.8 & 1.13 & 0.3451 \\
Biological yield,$\%$ & 58.6 & 63.1 & 58.4 & 56.8 & 0.63 & 0.0091 \\
\hline
\end{tabular}

${ }^{\text {a }}$ Diets consisted of the level of supplementing (or not) with mulberry forage on DM basis of BW, i.e. M-1: mulberry at $1 \%$ (DM basis) of lambs' BW; M-0.75: mulberry at $0.75 \%$ plus $0.1 \mathrm{~kg} / \mathrm{lamb} /$ day of concentrate; M-0.50: mulberry at $0.50 \%$ plus $0.2 \mathrm{~kg}$ of concentrate; and M-0: supplementing basal diet with $0.3 \mathrm{~kg}$ of concentrate (control; without mulberry). The forage basal diet consisted of a mixture of Pennisetum purpureum (first 90 days) or Megathyrsus maximus cv. Likoni and sugarcane-Saccharum officinarum - beginning of the 90 days. A prepared pre-mixture of sugarcane molasses with urea $(3 \%)$ was individually and daily distributed $(100 \mathrm{~g} / \mathrm{lamb} /$ day $)$ as a readily fermentable carbohydrate source to all lambs. Mineral salts and clean and fresh water were constantly available ad libitum

${ }^{\mathrm{b}}$ Biological yield $=[(\mathrm{CCW} / \mathrm{EBW}) \times 100]$ for animal feeding in the tropics were largely discussed by González-García and Martín Martín (2016). Mulberry forage banks respond to the objectives of looking for local animal production systems with self-sufficiency in forage production that align with whole-farm systems and address natural resource management issues such as organic matter recycling

Table 5 Economic feasibility of fattening lambs' diets with different levels of commercial concentrate replaced by mulberry forage

\begin{tabular}{|c|c|c|c|c|c|}
\hline \multirow{2}{*}{\multicolumn{2}{|c|}{ Item }} & \multicolumn{4}{|c|}{ Experimental diet } \\
\hline & & $\mathrm{M}-0$ & M- 0.50 & M-0.75 & M-1 \\
\hline \multicolumn{2}{|c|}{ Basal roughage ${ }^{\mathrm{a}}, \mathrm{CUP}$} & 5.6 & 5.4 & 5.1 & 4.6 \\
\hline \multicolumn{2}{|c|}{ Concentrate cost. CUP } & 8.7 & 5.4 & 2.7 & 0 \\
\hline \multicolumn{2}{|c|}{ Mulberry forage cost, CUP } & 0 & 1.2 & 1.8 & 2.3 \\
\hline \multicolumn{2}{|c|}{ Molasses $3 \%$ urea cost. CUP } & 0.18 & 0.18 & 0.18 & 0.18 \\
\hline \multicolumn{2}{|c|}{ Mineral salts cost, CUP } & 0.03 & 0.03 & 0.03 & 0.03 \\
\hline \multirow[t]{2}{*}{ Total feeding cost } & CUP & 14.5 & 12.2 & 9.8 & 7.2 \\
\hline & $\mathrm{USD}^{\mathrm{b}}$ & 0.6 & 0.5 & 0.4 & 0.3 \\
\hline \multicolumn{2}{|l|}{$\mathrm{ADG}, \mathrm{g} / \mathrm{lamb} / \mathrm{day}$} & 97 & 91 & 93 & 71 \\
\hline \multicolumn{2}{|c|}{ Cost of $\mathrm{ADG}^{\mathrm{c}}$} & 0.15 & 0.13 & 0.11 & 0.10 \\
\hline \multicolumn{2}{|c|}{ Economical daily gains ${ }^{\mathrm{d}}$} & 7.8 & 7.3 & 7.4 & 5.7 \\
\hline \multicolumn{2}{|c|}{ Profitability } & 7.6 & 7.1 & 7.3 & 5.6 \\
\hline
\end{tabular}

${ }^{a}$ Indicative local market prices per ingredient, used for calculations, were as follows: basal roughage (10 CUP/kg); concentrate (30 CUP/kg); mulberry forage ( $8 \mathrm{CUP} / \mathrm{kg})$; sugarcane molasses $3 \%$ urea $(2 \mathrm{CUP} / \mathrm{kg})$; mineral salts $(0.5 \mathrm{CUP} / \mathrm{kg})$

${ }^{\mathrm{b}}$ Conversion rate: $1 \mathrm{USD}=24 \mathrm{CUP}$

${ }^{\mathrm{c}}$ Cost of $\mathrm{AGD}=$ total ration cost $(\mathrm{CUP}) / \mathrm{ADG}$

${ }^{\mathrm{d}}$ Average total daily gain (CUP/lamb) as a function of the ADG and an indicative local market price per kilogram of lamb alive (1 $\mathrm{kg}=80 \mathrm{CUP})$

${ }^{\mathrm{e}}$ Economical daily gains - cost of ADG (CUP) and other life cycle processes. Positive animal responses have been obtained across different animal physiological or productive stages, both in meat (beef cattle, sheep and goats) and dairy (cattle, goats) production purposes systems (GonzálezGarcía and Martín Martín 2016).

The differences we found in DMI (Table 3) could be the indirect resultant of the differences in the energy feed sources offered to each group, i.e. different energy pools coming from concentrate and/or mulberry forage. Furthermore, the lower $\mathrm{BW}$ progression found in the $\mathrm{M}-1$ group was the consequence of the lower total DMI and their concomitant lower ADG obtained in this group (Table 3). The effective degradability of DM in the rumen is thought to be improved when combining more than one source, like concentrate and mulberry which was the case of M-0.75 and M-0.50. Feed intake could be enhanced or limited depending on the magnitude and development of a series of biochemical reactions in the rumen resulting from a synchronization of several protein and energy sources available from the diet. The mulberry and concentrate, as supplements with high ruminal degradability, may have significantly contributed to the activities of cellulolytic bacteria, microbial growth and the overall ruminal digestion efficiency (McAllister et al. 1994; Suárez et al. 2007). All these elements could result in different levels of palatability, consequently probably influencing individual feed intakes and, finally, animal response.

Compared to offering P. purpureum, a higher supply of simple or soluble sugars (glucose, fructose and sucrose) was expected when the mixture of guinea grass and sugarcane was distributed in the last month of the experiment (Fig. 1). However, this change in the roughage basal diet at this point 
did not induce an additional effect on the measured parameters across the different diets (e.g. DMI). Differences between treatments were maintained with the same tendencies (e.g. Fig. 2) which corroborate this statement.

Positive productive results including different levels of mulberry have been reported by others in the feeding of sheep (Pacheco et al. 2002), and our ADG values were similar or higher than those reported by Ríos et al. (2005) and Vargas et al. (2002) using crossed Pelibuey lambs and others with tropical hair breeds and feeding high amounts of imported concentrates and irrigated and fertilized pastures (Anindo et al. 1998; Pineda et al. 1998).

Our results in carcass yield fall in the average carcass yield values (40-50\%) argued by Perón (2009) for the Cuban Pelibuey lambs and were lower than the values reported by Leyva et al. (2007) and Ortiz et al. (2009) but similar to those found by Marshall et al. (2001).

We speculate that increasing the substitution of concentrate by mulberry forage positively affected the lamb meat quality (i.e. colour, flavour, intramuscular fat content, etc). This was not studied in our experiment but subjective observation at slaughtering evidenced that, e.g. muscles (Longissimus dorsi) and main cuts (leg and loin) were darker in the carcass of lambs fed more mulberry forage (less concentrate). Differences in meat colour and flavour between ruminants fed concentrates or allowed to graze pastures were reviewed by Priolo et al. (2001). In agreement with our observation, meat was reported to be darker in grazing animals probably due to variations in the ultimate $\mathrm{pH}$ and in intramuscular fat content (higher in concentrate-fed animals).

Archimède et al. (2008) in another study evaluating the growth performances and carcass traits of Ovin Martinik lambs fed several forage to concentrate ratios reported that growth (134-188 g/day) and feed/gain ratios (7.0-5.7) significantly improved with the increase of the concentrate in the ration. Values of ADG and feed/gain ratios were better that those obtained in our study, which is directly related to the higher DMI obtained when compared to those found in our study $\left(75,79,82\right.$ and $80 \mathrm{~g} \mathrm{DM} \mathrm{kg} \mathrm{BW}{ }^{0.75}$ for diets M-1, $\mathrm{M}-0.75, \mathrm{M}-0.50$ and $\mathrm{M}-0$, respectively). The total DMI and digestibility increased with the rate of concentrate inclusion at 82 vs. $97 \mathrm{~g} \mathrm{DM} \mathrm{kg} \mathrm{BW} \mathrm{BW}^{0.75}$ and 65 vs. $73 \%$, respectively, between the two extreme groups (including from 0 to $600 \mathrm{~g}$ of concentrate/lamb/day), whereas forage DMI decreased.

The feed conversion efficiencies in the present study were in agreement with those obtained by Marshall et al. (2001) using hay and a mixture of corn meal in confined Pelibuey lambs but are lower than those reported by Reyes et al. (2009). One could assume that feed efficiency was compromised with the gradual substitution of concentrate by mulberry. However, a deeper analysis must be done regarding the price of imported raw materials included in the concentrate and the final economic balance of the diets. Despite the reduction in feed conversion, increasing the level of mulberry forage significantly reduced the cost of production of $1 \mathrm{~kg}$ of lamb (Table 3) and the overall diet costs (i.e. from 14.5 in M-0 to 7.2 CUP per kg of total diet in the M-1 group; Table 5). This seems logical as the unitary cost of the mulberry forage is four-folds cheaper than that of commercial concentrate. When considering the ADG results, no differences were observed between the M- 0.75 and M- 1 diets regarding the cost to produce $1 \mathrm{~g}$ of ADG. These diets presented the lowest values for this parameter when compared to the control and M-0.5. The M-0.75 showed economical gains and profitability close to the values obtained for the control diet using the highest amount of imported concentrate.

\section{Conclusion}

Using rich and locally available feed resources as alternative supplements like mulberry foliage constitutes a sound option in the design of sustainable and productive feeding systems in the tropics. Without compromising animal productivity, replacing imported concentrate while increasing the level of substitution of mulberry in the ration of fattening lambs significantly reduced the overall feeding cost in our experiment. Optimum results were obtained including the mulberry forage at $0.75 \%$ of BW (M-0.75 diet), which presented voluntary feed intakes, growth rates, carcass yields, economical gains and profitability rates close to those obtained in the control diet offering just concentrate.

Thus, under the conditions of this study, it is recommended to use the M-75 diet. Nevertheless, further studies must be conducted for optimizing energy/protein ratios with different ingredients in the diet while searching to increase feed intake and lamb growth rates in tropical hair lamb genotypes, similar to that used in this study.

Acknowledgements The authors acknowledge the Ministry of Science and Technology (Ministerio de Ciencia y Tecnología, MICIT) and the National Board of Scientific Researches (Consejo Nacional para Investigaciones Cientificas y Tecnológicas, CONICIT) of Costa Rica for their financial support. Researches were supported by a National Research Project of the Human Food Program of Cuba (PH131LH-0072). The authors give thanks also to the anonymous reviewers which contributed to improve the quality of the manuscript with their helpful comments, remarks and recommendations.

\section{Compliance with ethical standards}

Conflict of interest The authors declare that they have no conflicts of interest. 


\section{References}

Albuerne, R., Delgado, A., Perón, N., Perera, A., 1996. Suplementación con caña de azúcar y urea para la ceba de corderos. Revista de Reproducción Animal, 22, 37-43.

Anindo D., Toé F., Tembely S., Mukasa-Mugerwa E., Lahlou-Kassi A., Sovani S., 1998. Effect of molasses-urea-block (MUB) on dry matter intake, growth, reproductive performance and control of gastrointestinal nematode infection of grazing Menz ram lambs. Small Ruminant Research, 27, 63-71.

Archimède, H., Pellonde, P., Despois, P., Etienne, T., Alexandre, G., 2008. Growth performances and carcass traits of Ovin Martinik lambs fed various ratios of tropical forage to concentrate under intensive conditions. Small Ruminant Research, 75(2-3), 162-170.

Association of Official Analytical Chemists, 1990. Official Methods of Analysis. 15th ed. AOAC, Arlington, VA.

Borroto A., Molina A., Mesa M., Baéz I., Pérez C., 1991. Sistema de ceba ovina con subproductos agrícolas de cítricos. Revista de Producción Animal, 6(1), 11-17.

Borroto, A., Mazorra, C.A., Pérez, R., Fontes, D., Borroto, M., Cubillas, N., Gutiérrez, I., 2007. La potencialidad alimentaria y los sistemas de producción ovina para una finca citrícola en Cuba. Revista Cubana de Ciencia Agrícola, 41, 3-12.

Cáceres, O., Ojeda, F., González, E., Arece, J., Simón, L., Lamela, L., Milera, M., Iglesias, J.M., Esperance, M., Montejo, I.L. and Soca, M., 2002. Valor nutritivo de recursos forrajeros tropicales para los rumiantes. [cd-rom]. Tablas de valor nutritivo. EEPF "Indio Hatuey". Matanzas, Cuba.

Doran, M.P., Laca, E.A., Sainz, R.D., 2007. Total tract and rumen digestibility of mulberry foliage (Morus alba), alfalfa hay and oat hay in sheep. Animal Feed Sciences and Technology, 138, 239-253.

FAOSTAT, 2015. FAO Statistical database. Production and live animals stocks sheet. Food and Agricultural Organization of the United Nations Statistical databases. Retrieved July, 2015 from http://faostat3.fao.org/download/Q/QA/E

Fonseca, N., 2003. Contribución al estudio de la alimentación del ovino Pelibuey en Cuba. PhD Thesis, University of Granma (Bayamo, Cuba) and Institute of Animal Science (Havane, Cuba), http://www. bibliociencias.cu/gsdl/collect/tesis/index/assoc/HASHf108.dir/doc.pdf (accessed 21.03.2014).

Fonseca, N., Miranda, O., Costa, P., La O, M., Ponce, I., 2011. Productive behaviour of the ovine Pelibuey in the stage of growth-bait. Revista Electrónica Granma Ciencia, 15, 1-6, http://www.grciencia.granma. inf.cu/2011_15_n1_a14.html

González, E. Ortega, M., Arece, J., Cáceres, O., 2001. Efecto de diferentes niveles de morera (Morus alba) en el consumo y el crecimiento de cabritas destetadas. Pastos y Forrajes, 24, 347-352.

González-García, E. and Martín Martín, G., 2016. Biomass yield and nutrient content of a tropical mulberry forage bank: effects of season, harvest frequency and fertilisation rate. Grass and Forage Science, (Online DOI: 10.1111/gfs.12227).

González-García, E., Arece, J., Archimède, H., Gomarín, P.P., Cáceres, O., 2008. Productive response of tropical lambs reared in two contrasting management systems after weaning and using woody forage species. Livestock ResEarch for Rural Development Volume 20, Article \#185. Retrieved July 20, 2015, from http://www.lrrd. org/lrrd20/11/gonz20185.htm

Herrera, J., Jordán, H., Senra, A.F., 2010. Management and feeding aspects of the Pelibuey sheep breeder in Cuba. Cuban Journal of Agricultural Science, 44(3), 205-213.

Kadim, I. T., Mahgoub, O., Al-Ajmi, D.S., Al-Maqbaly, R.S., Al-Saqri, N.M., Ritchie, A., 2004. An evaluation of the growth, carcass and meat quality characteristics of Omani goat breeds. Meat Science, 66(1), 203-210.
Kandylis, K., Hadjigeorgiou, I., Harizanis, P., 2009. The nutritive value of mulberry leaves (Morus alba) as a feed supplemented for sheep. Tropical Animal Health and Production, 41, 17-24.

Leyva, C., Ortiz, A., Valdivié, M., 2007. Sustainable production of sheep meat from the fruit and leaf meal of the breadfruit tree (Artocarpus altilis). Pastos y Forrajes, 30, 373-380.

Marshall, W., Bertot, J.A., Delgado, A., Collantes, M., Corchado, A., 2001. Productive performance and characteristics of the carcass of Pelibuey lambs fed with hay and supplemented with soybean meal and chicken dung. Revista de Producción AnimAl, 13, 43-47, http://www.reduc.edu.cu/147/01/2/14701209.pdf (accessed 13.05.2014).

Martín, G.J., Noda, Y., Pentón, G., García, D.E., García, F., González, E., Ojeda, F., Milera, M., Lopez, O., Ly, J., Leiva, L., Arece, J., 2007. Mulberry (Morus alba, Linn.): a species of interest for livestock production. Pastos y Forrajes, 30, 3-19.

Mazorra, C., Borges, G., Blanco, M., Marrero, P., Borroto, A., Sorís, A.L., 2003. Influencia de la adaptación al ambiente de pastoreo en la conducta de ovinos integrados a plantaciones citrícolas. Zootecnia Tropical, 21(1), 57-71.

Mazorra, C., Blanco, M., Barrabí, M., 2004. Influencia de la suplementación con hollejo de cítrico sobre el comportamiento en pastoreo de ovinos en crecimiento integrados a plantaciones citrícolas durante la época lluviosa. Zootecnia Tropical, 22(4) Retrieved July 1st, 2015, from http://www.scielo.org.ve/scielo. php?pid=S0798-72692004000400004\&script=sci arttext.

McAllister, T.A., Bae, H.D., Jones, G.A., Cheng, K.J., 1994. Microbial attachment and feed digestion in the rumen. Journal of Animal Science, 72, 3004-3018.

Nguyen, X.B., Giang, V.D., Ngoan, L.D., 2005. Ensiling of mulberry foliage (Morus alba) and the nutritive value of mulberry foliage silage for goats in central Vietnam. Livestock Research for Rural Development, 17, 1-9, http://www.lrrd.org/lrrd17/2/ba17015.htm (accessed 15.05.2014)

Ortiz, A., Elías, A., Valdivié, M., 2009. Using different sources of chicken dung as supplement in fattening lambs at grazing. Cuban Journal of Agricultural Science, 43, 245-249.

Pacheco, D., Lara, P.E., Sanginés, R., 2002. Different levels of mulberry (Morus alba) forage in the ration of fattening lambs. In Proceedings of V Internacional Workshop in Sylvopastoral Systems and First Regional Meeting on Mulberry, Experimental Station on Grass and Forages "Indio Hatuey", Matanzas, Cuba.

Pedraza, R.M., Mauriño, C., Gómez, J.E., Valdés, V., Chaviano, A., 1995. Alimentación post-destete de ovinos pelibuey con miel "B", heno y mezclas basadas en derivados de la caña de azúcar. Livestock Research for Rural Development Volume 7(2), Article \#185. Retrieved June 12, 2015, from http://www.lrrd.org/lrrd7/2/10.htm

Perera, A.J., Albuernez, R., 1993. Producción intensiva de carne ovina con miel/urea. Preceba y fraccionamiento del suplemento proteico. Revista de Producción Animal, 7(1-2), 5-8.

Perón, N., 2009. Manual or production guide for the Pelibuey sheep in Cuba. Cuban Association of Animal Production (ACPA), Havana, Cuba.

Pineda, J., Palma J.M., Haenlein G.F.W., Galina M.A., 1998. Fattening of Pelibuey hair sheep and crossbreds (Rambouillet-Dorset $\times$ Pelibuey) in the Mexican tropics. Small Ruminant Research, 27(3), 263-266.

Priolo, A., Micol, D., Agabriel, J., 2001. Effects of grass feeding systems on ruminant meat colour and flavour. A review. Animal Research, $50,185-200$.

Reyes, N., Rodríguez, R., Mendieta, B., Mejía, L., Mora, A., 2009. The effects of supplementing Moringa oleifera on productive performance of lambs fed a basal diet with guinea (Panicum maximun Jacq.) grass. La Calera, 9, 60-69, http://lacalera.una.edu.ni/index. $\mathrm{php} / \mathrm{calera} /$ article/view/134/134 (accessed 13.04.2014).

Ríos, L., Rondón, Z., Combellas, J., Álvarez, R., 2005. Using mulberry (Morus sp.) and mataratón (Gliricidia sepium) forages for 
substituting concentrates in growing labs diets. Zootecnia Tropical, 23, 49-60, http://www.scielo.org.ve/scielo.php?pid=S0798$72692005000100005 \&$ script $=$ sci arttext (accessed 18.06.2014).

Salinas-Chavira, J., Castillo-Martínez, O., Ramirez-Bribiesca, J.E., Mellado, M., 2011. Effect of increasing levels of white mulberry leaves (Morus alba) on ruminal dry matter degradability in lambs. Tropical Animal Health and Production, 43(5), 995-999.

SAS Statistical Analysis Systems Institute (SAS). Version 9.3. SAS language guide for personal computers. Cary, NC: SAS Institute Inc; 2003.

Soca, M., Ojeda, F., García, D.E., Soca, M., 2010. Effects of feeding mulberry (Morus alba) forage on the productive and health indicators of grazing calves. Pastos y Forrajes, 33, 1-10.

Suárez, B. J., Van Reenen, C.G., Beldman, G., Van Delen, J., Dijkstra, J., Gerrits, W.J., 2007. Effects of supplementing concentrates differing in carbohydrate composition in veal calf diets: I. Animal performance and rumen fermentation characteristics. Journal of Dairy Science, 89, 4365-4375.
Suassuna, J.M.A., Santos, E.M., Silva de Oliveira, J., de Azevedo, P.S., de Sousa, W.H., Araujo Pinho, R.M., de Farias Ramos, J.P., Carvalho Bezerra, H.F., 2014. Carcass characteristics of lambs fed diets containing silage of different genotypes of sorghum. Revista Brasileira de Zootecnia, 43, 80-85,

Van Soest, P.J., Robertson, J.B., Lewis, B.A., 1991. Methods for dietary fiber, neutral detergent fiber and nonstarch polysaccharides in relation to animal nutrition. Journal of Dairy Science, 74, 3583-3597.

Vargas, S., Franco, R., Suárez, D., Quiñones, R., Ríos, L., Artiles, J., 2002. Comportamiento productivo de ovinos mestizos Pelibuey en crecimiento, utilizando dos niveles de morera (Morus alba) y CT-115 (hierba elefante cubana) como forraje base. In Proceedings of $\mathrm{V}$ Internacional Workshop in Sylvopastoral Systems and First Regional Meeting on Mulberry, Experimental Station on Grass and Forages "Indio Hatuey", Matanzas, Cuba. 